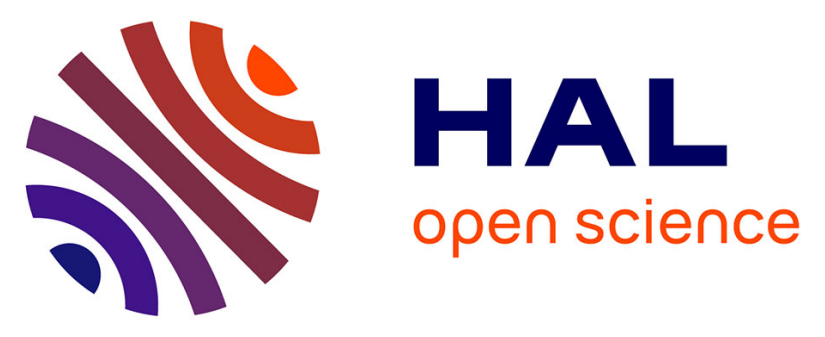

\title{
Brittle and ductile removal modes observed during diamond turning of carbon nanotube composites
}

\author{
Renato Goulart Jasinevicius, Marcello B. R. Andreeta, João S. Fossa, Antônio \\ Carlos Hernandez-Rodriguez, Jaime G. Duduch, Philippe Demont, Pascal \\ Puech
}

\section{To cite this version:}

Renato Goulart Jasinevicius, Marcello B. R. Andreeta, João S. Fossa, Antônio Carlos HernandezRodriguez, Jaime G. Duduch, et al.. Brittle and ductile removal modes observed during diamond turning of carbon nanotube composites. Proceedings of the Institution of Mechanical Engineers, Part B: Journal of Engineering Manufacture, 2009, vol. 223 ( $\mathrm{n}^{\circ}$ 1), pp. 1-8. 10.1243/09544054JEM1257. hal-01110531

\section{HAL Id: hal-01110531 \\ https://hal.science/hal-01110531}

Submitted on 28 Jan 2015

HAL is a multi-disciplinary open access archive for the deposit and dissemination of scientific research documents, whether they are published or not. The documents may come from teaching and research institutions in France or abroad, or from public or private research centers.
L'archive ouverte pluridisciplinaire $\mathbf{H A L}$, est destinée au dépôt et à la diffusion de documents scientifiques de niveau recherche, publiés ou non, émanant des établissements d'enseignement et de recherche français ou étrangers, des laboratoires publics ou privés. 


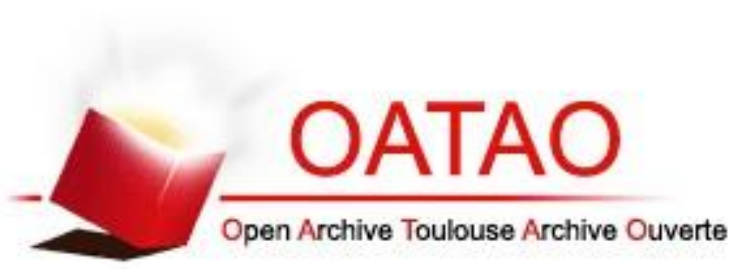

\section{Open Archive Toulouse Archive Ouverte (OATAO)}

OATAO is an open access repository that collects the work of Toulouse researchers and makes it freely available over the web where possible.

This is an author-deposited version published in: http://oatao.univ-toulouse.fr/ Eprints ID: 8662

Identification number: DOI:10.1243/09544054JEM1257

Official URL: http://dx.doi.org/10.1243/09544054JEM1257

\section{To cite this version:}

Jasinevicius, Renato Goulart and Andreeta, Marcello B. R. and Fossa, João S. and Hernandez-Rodriguez, Antônio Carlos and Duduch, Jaime G. and Demont, Philippe and Puech, Pascal Brittle and ductile removal modes observed during diamond turning of carbon nanotube composites. (2009) Proceedings of the Institution of Mechanical Engineers, Part B: Journal of Engineering Manufacture, vol. $223\left(\mathrm{n}^{\circ} 1\right)$. pp. 1-8. ISSN 0954-4054

Any correspondence concerning this service should be sent to the repository administrator: staff-oatao@inp-toulouse.fr 


\title{
Brittle and ductile removal modes observed during diamond turning of carbon nanotube composites
}

\author{
R G Jasinevicius ${ }^{1 *}$, M R B Andreeta ${ }^{2}$, J S Fossa ${ }^{2}$, A C Hernandes ${ }^{2}$, J G Duduch ${ }^{1}$, P Demont ${ }^{3}$, and P Puech \\ ${ }^{1}$ Departmento de Engenheria Mecânica, Universidade de São Paulo, São Carlos, São Paulo, Brazil \\ ${ }^{2}$ Grupo de Crescimento de Cristais e Materiais Cerâmicos, Universidade de Sâo Paulo, Sâo Carlos, Sâo Paulo, Brazil \\ ${ }^{3}$ Laboratoire de Physique des Polymères, Institut Carnot-Cirimat, Université Paul Sabatier Toulouse III, Toulouse, \\ France \\ ${ }^{4}$ CEMES, Toulouse, France
}

DOI: 10.1243/09544054JEM1257

\begin{abstract}
Ultraprecision diamond turning was used to evaluate the surface integrity of a carbon nanotube (CNT) composite as a function of the cutting conditions and the percentage of CNT in the epoxy matrix. The effects of cutting conditions on the chip morphology and surface roughness were analysed. The results showed that an increase in the percentage of CNT may influence the mechanism of material removal and consequently improve the quality of the machined surface. When smaller quantities of CNT (0.02 and $0.07 \mathrm{wt} \%)$ are present in the matrix, microcracks form within the cutting grooves (perpendicular to the cutting direction). This indicates that the amount of CNT on the epoxy matrix may have a direct influence on the mechanical properties of these materials. Chips removed from the CNT composite samples were analysed by scanning electron microscopy in order to correlate the material removal mechanism and the surface generation process. The area average surface roughness $S_{\mathrm{a}}$ was influenced by the material removal mechanism $\left(S_{\mathrm{a}}\right.$ ranging from 0.28 to $\left.1.1 \mu \mathrm{m}\right)$.
\end{abstract}

Keywords: carbon nanotubes, nanocomposite material, micromachining, single-point diamond turning, non-destructive evaluation, surface finish

\section{INTRODUCTION}

Ultraprecision diamond turning is an established machining technique applied to the manufacturing of several products such as contact lenses, mirrors, infra red lenses, etc. The variety of materials already studied in terms of machinability using single-point diamond tools range from optical polymers, nonferrous metals, and optical glasses to semiconductor crystals. The results obtained in terms of surface roughness and surface form may be smaller than a few tens of nanometres (peak to valley) and smaller than a few hundred nanometres respectively. The typical cutting conditions in ultraprecision diamond turning imply that the material removal process be

*Corresponding author: Departmento de Engenheria Mecânica, Escold de Engenharia de São Carlos, Universidade de São Paulo, C.P. 359, CEP 13566-590, São Carlos, São Paulo, Brazil. email: renatogj@sc.usp.br governed by the microinteraction between the diamond cutting edge (a few tens of nanometres) and the workpiece material. Because of this, the microstructure of the workpiece can play a fundamental role in the cutting results.

Considerable attention has been paid to carbon nanotubes (CNTs) owing to their outstanding mechanical properties and high electrical and thermal conductivity [1-5]. Adding CNTs to an epoxy matrix has the effect of increasing the electrical conductivity at low filling as a result of the low percolation threshold for nanotubes (between 0.04 and $0.2 \mathrm{wt} \%$ CNTs depending on the dispersion and amphiphilic molecule assistance) [6]. Consequently, improvement of the electrical and mechanical properties of composites has prompted many initiatives in recent years [7]. In terms of manufacturing engineering it is important to have materials such as CNT epoxy resin composites that present very high strength-weight and modulus-weight ratios. This can 
be done by decreasing the density of epoxy and increasing the amount of CNT in the matrix, which provides very good mechanical properties. Since turning is dynamic, new behaviours of the material could be expected with percolation because CNTs are good thermal conductors and can quickly dissipate the energy in the network. CNTs are still expensive, and changing the properties with a small amount is a challenge. With dynamic changes, an improvement can be expected in the material response to manufacturing processes and also in the lifetime of the product. For example, CNTs change the wear rate of tyres, contributing to energy savings, or stop crack propagation after an impact.

It is known that surface properties affect the performance of high-quality components/products. Mechanical processes of material removal, applied to the manufacturing of industrial parts and components, may generate deleterious damage to the mechanical properties of materials. Several factors affect the surface integrity of high-quality components when they are machined, including surface roughness, microstructure, residual stresses, and microhardness variation.

In addition, very little effort has been made so far to change the CNT composite surface and bulk properties induced by industrial processing methods [8]. Surface integrity is of extreme importance in order to guarantee the performance of the material during its application. For example, surface roughness may drastically affect the fatigue properties of these materials. The comprehension of $\mathrm{CNT} / \mathrm{ma}-$ chining and its effects upon material response is considered an important issue for applications in the aeronautic industry. For the tyre industry, energy saving with low rolling resistance and low wear rates is also an interesting challenge.

Based upon the aspects pointed out, it is important to understand the mechanism of material removal in machining in order to improve the material response to manufacturing processes in terms of surface roughness, form, and surface damage.

The single-point diamond turning process was used to evaluate the material removal mechanism and the surface integrity of a CNT composite in respect of two aspects: variation in cutting conditions and variation in the weight fraction of CNTs in the epoxy matrix.

\section{EXPERIMENTAL PROCEDURE}

Carbon nanotube-epoxy resin nanocomposite samples $(15 \mathrm{~mm} \times 30 \mathrm{~mm}$, and $1.5 \mathrm{~mm}$ thick) with different concentrations of CNT (see Table 1) were face turned with a round-nosed single-crystal diamond tool (Contour Fine Tooling ${ }^{\circledR}$ ). The CNTs were pre-
Table 1 Composition of the CNT epoxy resin samples

\begin{tabular}{lll}
\hline Sample & CNT content $(\mathrm{wt} \%)$ & Observation \\
\hline 1 & 0.02 & $\begin{array}{l}0.02 \text { per cent palmitic acid } \\
\text { Percolation }<0.04 \text { per cent }\end{array}$ \\
2 & 0.07 & \\
3 & 0.3 & $\begin{array}{l}0.3 \text { per cent palmitic acid } \\
\text { Percolation }<0.04 \text { per cent } \\
0.4 \text { per cent palmitic acid } \\
4\end{array}$ \\
& 0.4 & \begin{tabular}{l} 
Percolation $>0.15$ per cent \\
\hline
\end{tabular} \\
\hline
\end{tabular}

pared by the catalytic chemical vapour deposition method (CCVD). Selective reduction at $1000^{\circ} \mathrm{C}$ in a methane-hydrogen $\left(18 \% \mathrm{CH}_{4}\right)$ atmosphere of a solid solution of a transition metal oxide $\mathrm{Mg}_{0.95} \mathrm{Co}_{0.05}$ led to the formation of small-diameter CNTs with 1-3 walls (for more details, see references [6] to [8]). After the reaction, the unreacted catalytic particles were dissolved in diluted (3.7 per cent) hydrochloric acid and CNTs were recovered. High-resolution electron microscopy images show the presence of individual CNTs and small bundles of CNTs with an average diameter of $2.4 \mathrm{~nm}$. The nanotubes were mainly single walled (SW) and double walled (DW). A dispersion of CNTs in water was first kept in an ultrasonic bath for $1 \mathrm{~h}$ and stirred. No surfactants were used. CNT-epoxy resin composites were prepared by dispersion (in weight) of CNTs ranging from 0.04 to $0.4 \mathrm{wt} \%$. The liquid epoxy resin was added to the dilute suspension of nanotubes and water was evaporated at $100^{\circ} \mathrm{C}$. The mixture was then mechanically stirred for $1 \mathrm{~h}$ at $2000 \mathrm{r} / \mathrm{min}$. The hardener was added, and the whole mixture was mechanically stirred for $15 \mathrm{~min}$ and then cast into a teflon mould and degassed for $20 \mathrm{~min}$ under vacuum. The nanocomposite was cured at $120^{\circ} \mathrm{C}$ for $20 \mathrm{~min}$ and at $145^{\circ} \mathrm{C}$ for another $8 \mathrm{~h}$. In order to enhance CNT dispersion in the epoxy matrix, palmitic acid (PA) can be added as a dispersing agent before hardener addition. Other samples were prepared by varying the CNT content from 0.02 to $0.8 \mathrm{wt} \%$, with a CNT-PA weight ratio of $1: 1$.

The percolation threshold is associated with a change in the conductivity value from $10^{-15} \mathrm{~S} / \mathrm{cm}$ to $10^{-5} \mathrm{~S} / \mathrm{cm}$. Table 1 presents the values for the composites. The samples have been selected with a small amount of CNT in order to find what can be expected below and above the threshold. Sample 1 is an insulating nanocomposite because the CNT content is below the threshold percolation. Sample 2 ( $0.07 \mathrm{wt} \%$ CNTs) is very close to the threshold percolation, while samples 3 and 4 are largely above the threshold.

Single-point diamond turning tests were carried out on a commercially available ultraprecision diamond turning machine, the Aspheric Surface 
Generator Rank Pneumo ASG 2500. The cross-feed direction was outside to inside. The cutting tool had a nose radius of $0.76 \mathrm{~mm}$, a $0^{\circ}$ rake angle, and a $12^{\circ}$ clearance angle. No cutting fluid was used, as the material is very soft and there is no need for cooling or lubrication. The feed rate and depth of cut applied in the cutting tests are described in Table 2. The spindle speed was kept constant at $1000 \mathrm{r} / \mathrm{min}$. The test provided ductile- and brittlemode machining resulting in different surface finishes.

Table 2 Cutting conditions used in the face operation

\begin{tabular}{lll}
\hline Cutting condition/operation & $\begin{array}{l}\text { Feed rate } \\
(\mu \mathrm{m} / \mathrm{rev})\end{array}$ & $\begin{array}{l}\text { Depth of cut } \\
(\mu \mathrm{m})\end{array}$ \\
\hline Rough & 15 & 20 \\
Semi-finishing & 10 & 5 \\
Finishing & 5 & 1 \\
\hline
\end{tabular}

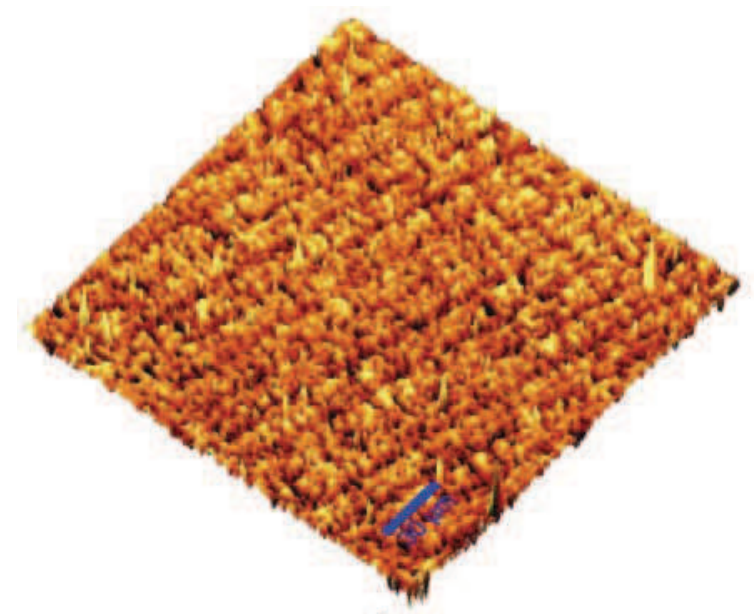

a)

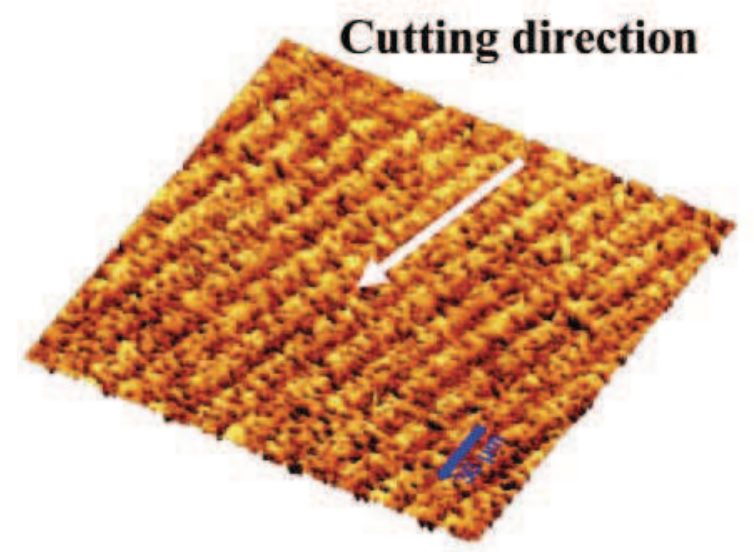

c)

\section{RESULTS AND DISCUSSION}

\subsection{Surface roughness results}

Figures 1(a) to (d) show three-dimensional AFM images of the samples cut under the same conditions (feed rate $15 \mu \mathrm{m} / \mathrm{rev}$, depth of cut $20 \mu \mathrm{m}$ ), diamond turned in the ductile and brittle modes. The cutting grooves are regularly spaced and run parallel with the cutting direction, which confirms the absence of chattering. Figures $1(\mathrm{a})$ and (b) show samples with the lowest CNT concentration. The feed marks of the tool are visible, but the surface shows small tears and pitting within the cutting grooves (across the cutting direction), most probably because of a more brittle cutting behaviour. This composite has a thermoset epoxy resin matrix, which also contributes to its brittleness. Cracks might originate at the tool tip and propagate into the newly formed surface, resulting in a fractured surface and adversely affecting the surface quality after diamond turning.

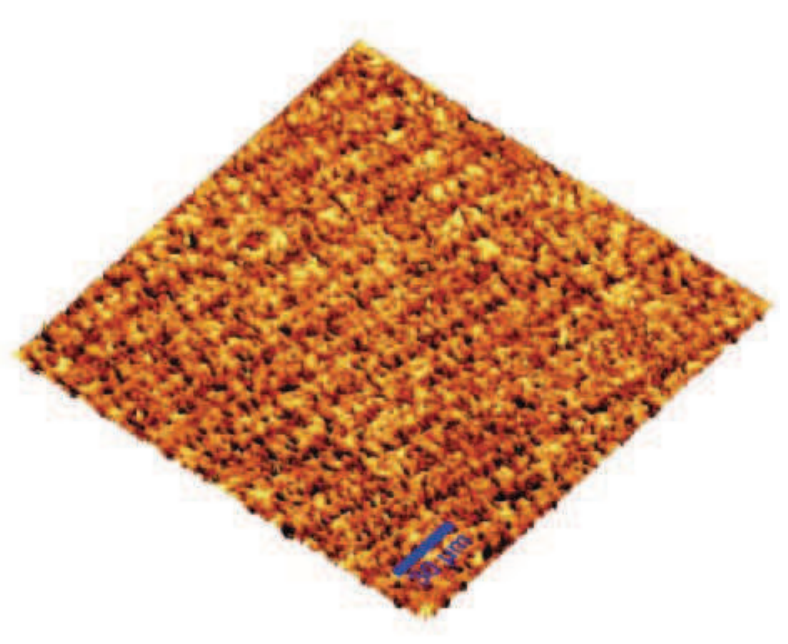

b)

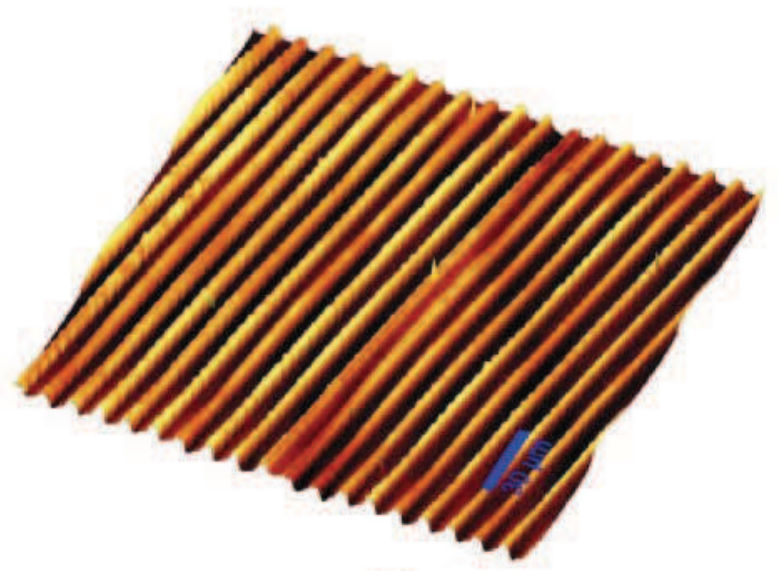

d)

Fig. 1 Three-dimensional images made by AFM of the surfaces generated under the rough cutting condition: (a) 0.02 wt\% CNTs; (b) 0.07 wt \% CNTs; (c) 0.3 wt \% CNTs; (d) 0.4 wt \% CNTs 
Table 3 Surface roughness analysis of the machined samples

\begin{tabular}{|c|c|c|c|c|c|c|}
\hline Sample & $\begin{array}{l}\text { CNT content } \\
\text { (wt \%) }\end{array}$ & $\begin{array}{l}\text { Feed rate } \\
(\mu \mathrm{m} / \mathrm{rev})\end{array}$ & $\begin{array}{l}\text { Depth of } \\
\text { cut }(\mu \mathrm{m})\end{array}$ & $S_{\mathrm{a}}(\mu \mathrm{m})$ & $S_{\mathrm{q}}(\mu \mathrm{m})$ & $\begin{array}{l}\text { Peak-to-valley } \\
(\mu \mathrm{m})\end{array}$ \\
\hline 1 & 0.02 & $\begin{array}{r}15 \\
10 \\
5\end{array}$ & $\begin{array}{r}20 \\
5 \\
1\end{array}$ & $\begin{array}{l}0.4534 \\
0.3609 \\
0.2666\end{array}$ & $\begin{array}{l}0.5417 \\
0.4424 \\
0.3047\end{array}$ & $\begin{array}{l}2.326 \\
1.992 \\
1.989\end{array}$ \\
\hline 2 & 0.07 & $\begin{array}{r}15 \\
10 \\
5\end{array}$ & $\begin{array}{r}20 \\
5 \\
1\end{array}$ & $\begin{array}{l}0.5339 \\
0.3729 \\
0.1982\end{array}$ & $\begin{array}{l}0.6004 \\
0.4406 \\
0.2360\end{array}$ & $\begin{array}{l}3.186 \\
2.700 \\
1.583\end{array}$ \\
\hline 3 & 0.3 & $\begin{array}{r}15 \\
10 \\
5\end{array}$ & $\begin{array}{r}20 \\
5 \\
1\end{array}$ & $\begin{array}{l}0.7326 \\
0.4864 \\
0.2564\end{array}$ & $\begin{array}{l}0.8734 \\
0.5961 \\
0.2892\end{array}$ & $\begin{array}{l}4.680 \\
3.356 \\
3.320\end{array}$ \\
\hline 4 & 0.4 & $\begin{array}{r}15 \\
10 \\
5\end{array}$ & $\begin{array}{r}20 \\
5 \\
1\end{array}$ & $\begin{array}{l}0.9100 \\
0.9404 \\
0.9595\end{array}$ & $\begin{array}{l}1.0579 \\
1.0137 \\
1.1228\end{array}$ & $\begin{array}{l}4.444 \\
4.867 \\
5.852\end{array}$ \\
\hline
\end{tabular}

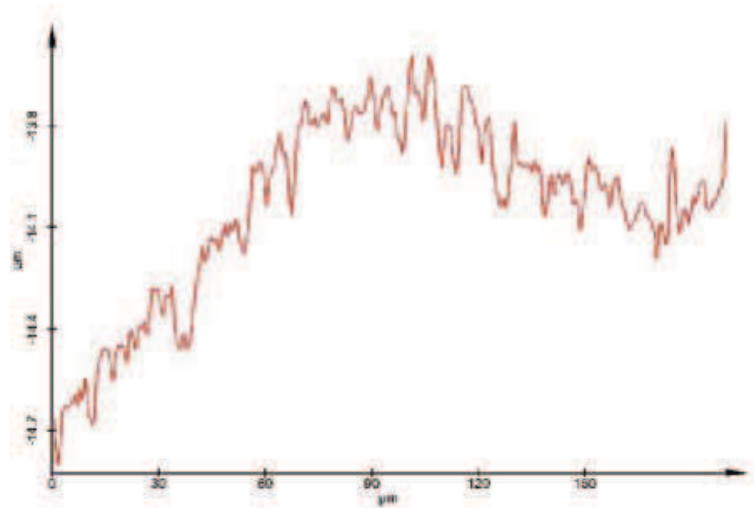

a)

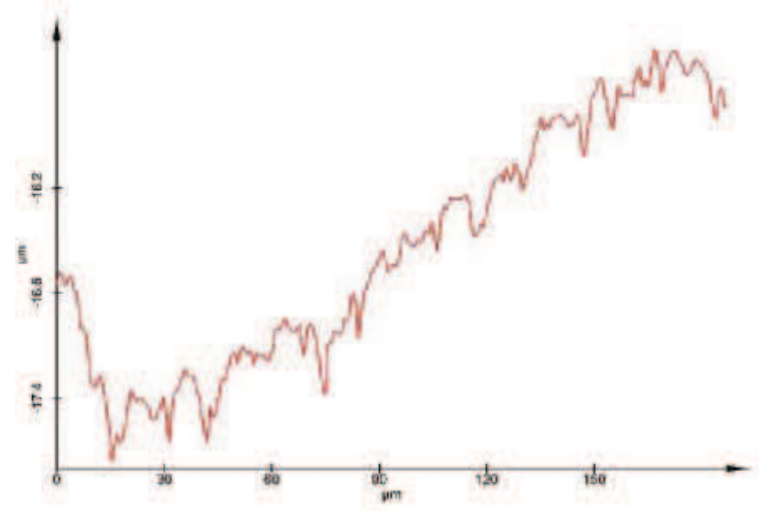

c)

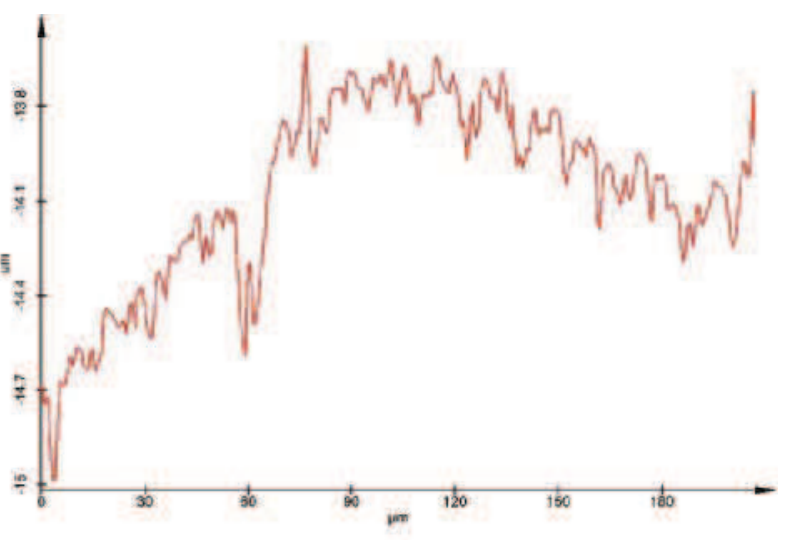

b)

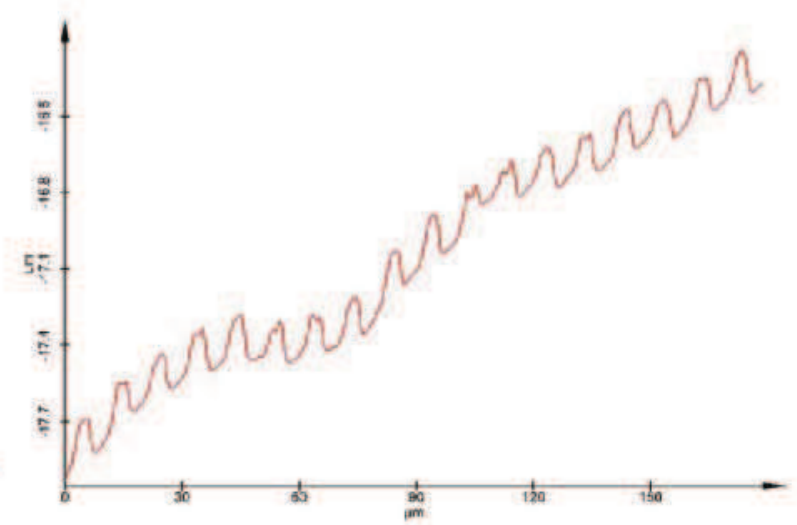

d)

Fig. 2 Cross-sectional profile of the machined surfaces cut under the roughening operation: (a) 0.02 wt \% CNTs; (b) 0.07 wt \% CNTs; (c) 0.3 wt \% CNTs; (d) 0.4 wt \% CNTs

The formation of microcracks seems to be related not only to the matrix being thermoset but also to the rake angle tool $\left(0^{\circ}\right)$. Carr and Feger [9] investigated the influence of the rake angle on the surface finish of a brittle material (Vespel). According to the authors, the rake angle influences the direction of the cutting force. Their results demonstrated that the resulting cutting force points into the workpiece, and the machined surface presented a strong pit formation when the rake angle was large and negative. It was also demonstrated that the force vector (resulting cutting force) points at the uncut surface when the rake angle is almost zero and reaches its most effective value when the rake angle is slightly positive (around $+2^{\circ}$ ). The resulting cutting force, in this case, points slightly to the uncut surface. Consequently, microcracks that are normally formed in front of the tool would not penetrate the cutting 


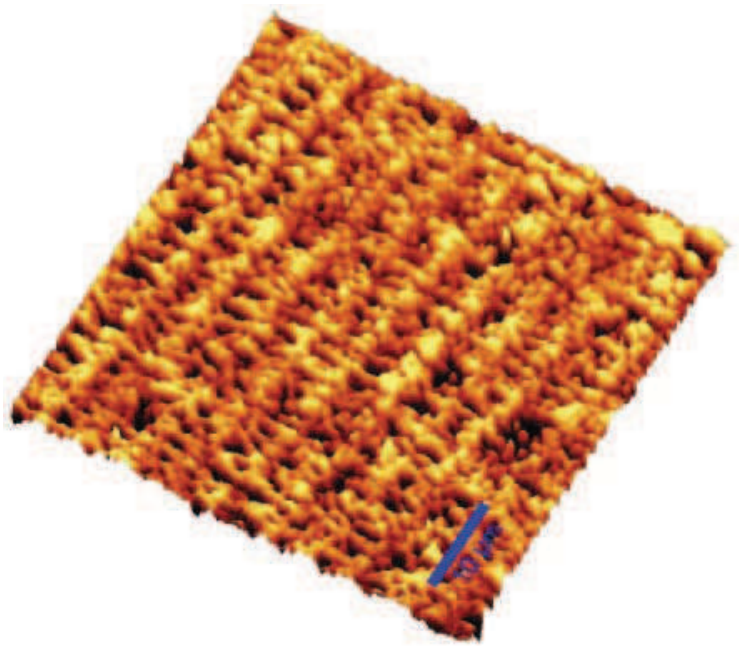

a)

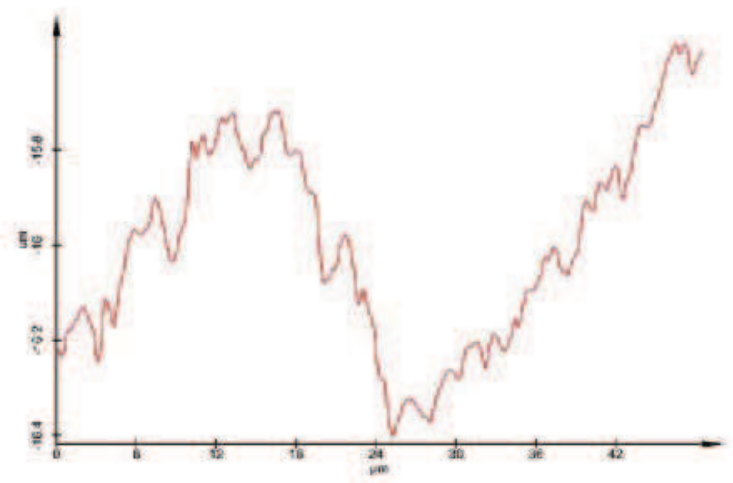

b)

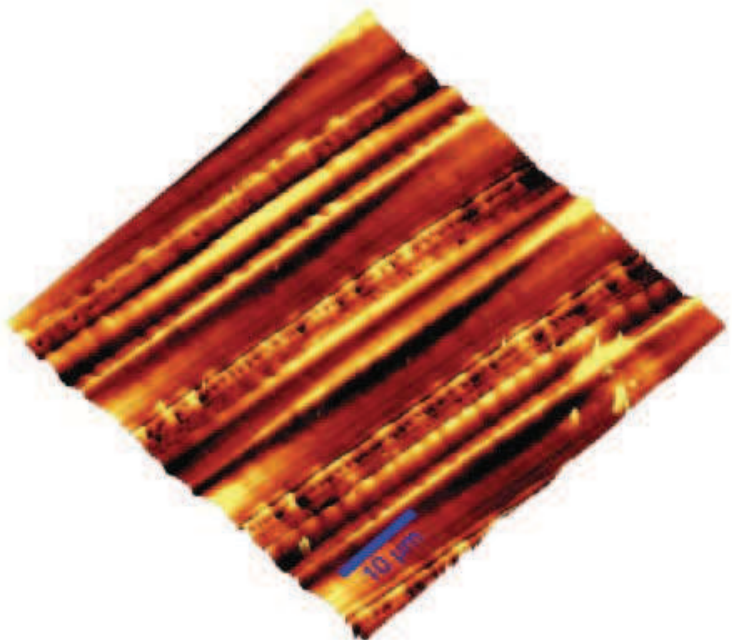

c)

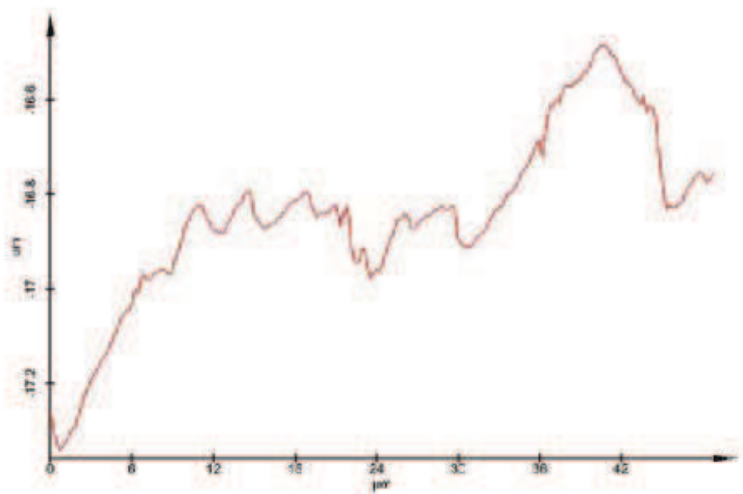

d)

Fig. 3 Three-dimensional images made by AFM, showing a closer view of the machined cut grooves of the machined samples under different cutting conditions and percentage CNT: (a) $0.07 \mathrm{wt} \% \mathrm{CNTs}$, feed rate $5 \mu \mathrm{m} / \mathrm{rev}$ (finishing cutting condition); (b) cross-sectional profile view of the machined surface; (c) $0.4 \mathrm{wt} \%$ CNTs, feed rate $15 \mu \mathrm{m} / \mathrm{rev}$ (rough cutting condition); (d) cross-sectional profile view of the machined surface

plane, leaving a crack-free surface. The area surface roughnesses $S_{\mathrm{a}}$ were 0.4534 and $0.5339 \mu \mathrm{m}$ (Figs 1(a) and (b) respectively). A closer examination of the machined surface (Fig. 1(c)) indicates that microtears are still present and brittle mode prevails, in spite of the increased concentration of CNT. The area surface roughness $S_{\mathrm{a}}$ also increases to $0.7326 \mu \mathrm{m}$. The sample with the highest concentration of CNT presented a different surface finish, as shown in Fig. 1(d). The cutting grooves can be clearly seen and do not present any signs of the brittle behaviour, characteristic of normal thermoplastic machining of, for example, PMMA [10]. This may be related to the difference in density of CNTs in the epoxy matrix. However, the area surface roughness increased to $0.9595 \mu \mathrm{m}$ for the finest finishing cutting condition. This is an unexpected result because the microtears within the cutting grooves in the samples with a lower concentration of CNTs should have resulted in larger values of surface roughness. The complete surface roughness results under different cutting conditions and compositions (wt \%) of CNTs are listed in Table 3.

The peak-to-valley results presented in Table 3 correspond to the sample cross-section (Figs 2(a) to (d)) presented in Fig. 1. The cross-sectional profile of the sample with no pits replicates with good fidelity the tool path (feed rate $15 \mu \mathrm{m} / \mathrm{rev}$ ), as shown in Fig. 2(d). The high surface roughness may be explained by an increase in material side flow during cutting. Figure 3 shows a comparison of two surfaces. Fig. 3(a) shows the three-dimensional image and Fig. 3(b) shows the cross-sectional profile of the machined surface under a feed rate of $5 \mu \mathrm{m} / \mathrm{rev}$ (finishing condition) with $0.07 \mathrm{wt} \%$ CNTs. Figure 3(c) shows the three-dimensional image and Fig. 3(d) shows 

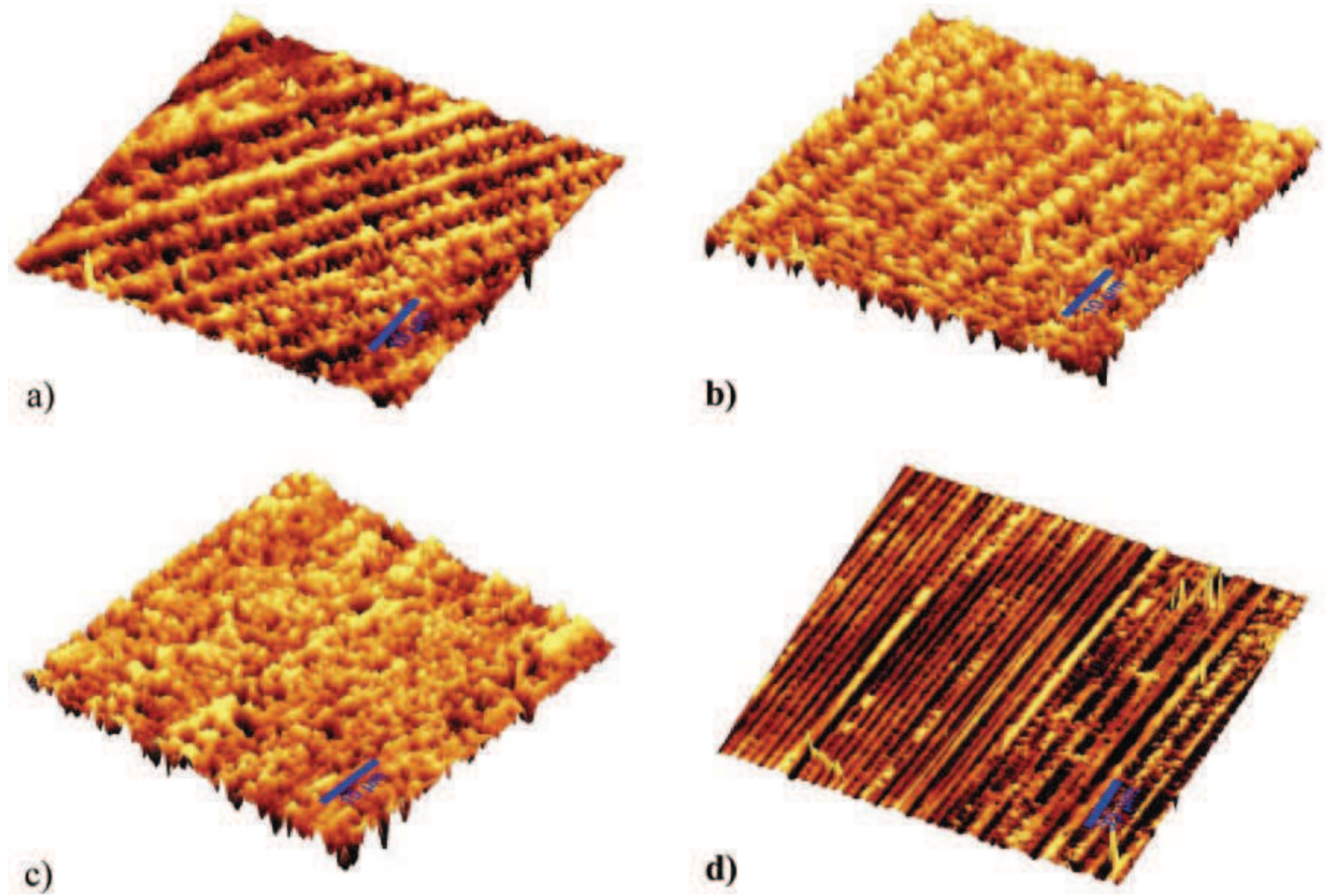

Fig. 4 Three-dimensional images made by AFM of the surfaces generated under the finish cutting condition: (a) 0.02 wt \% CNTs; (b) $0.07 \mathrm{wt} \%$ CNTs; (c) 0.3 wt \% CNTs; (d) $0.4 \mathrm{wt} \%$ CNTs

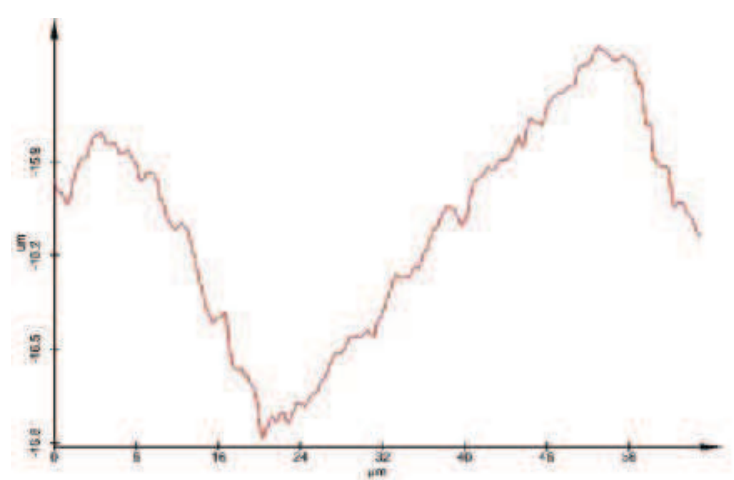

a)

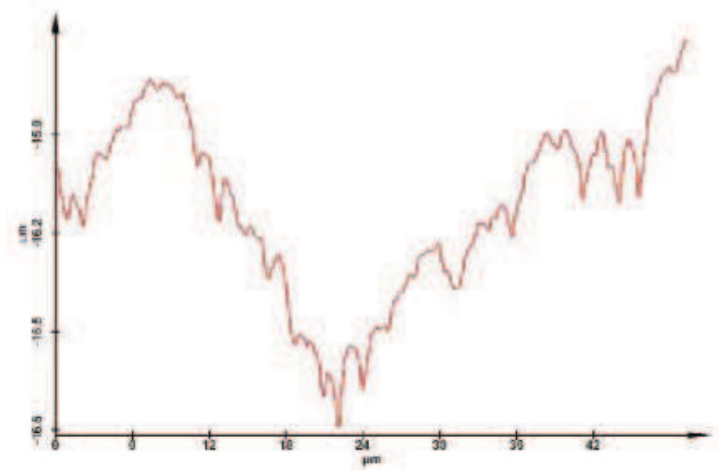

c)

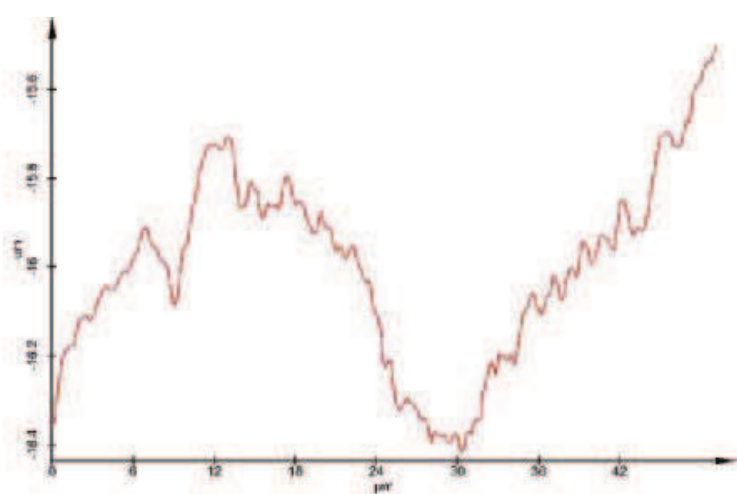

b)

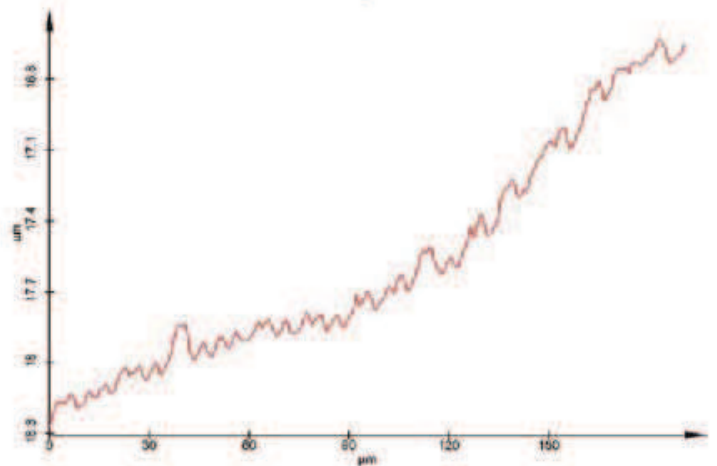

d)

Fig. 5 Cross-sectional profile of the machined surfaces cut under the finish operation: (a) 0.02 wt \% CNTs; (b) 0.07 wt \% CNTs; (c) 0.3 wt \% CNTs; (d) 0.4 wt \% CNTs 


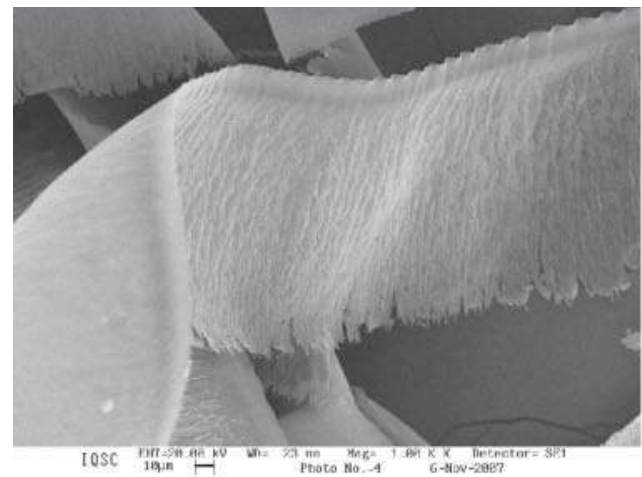

a)

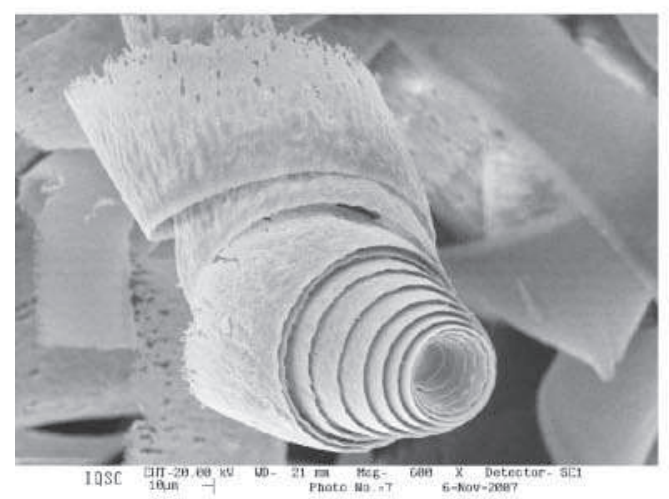

c)

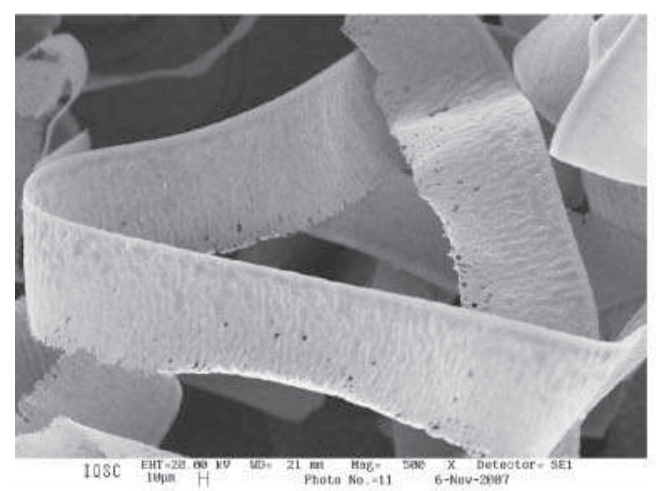

e)

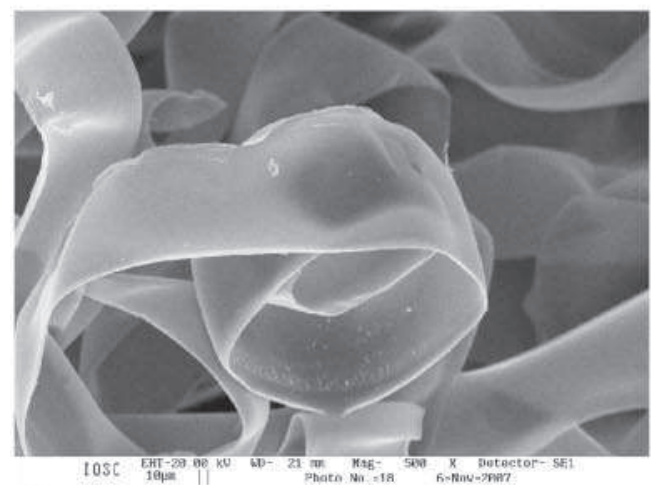

g)

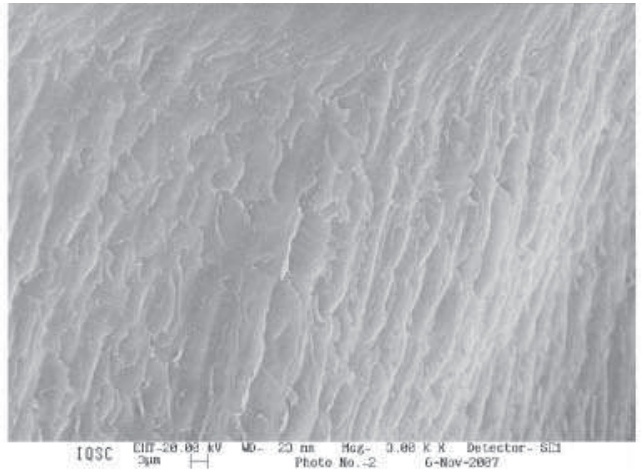

b)

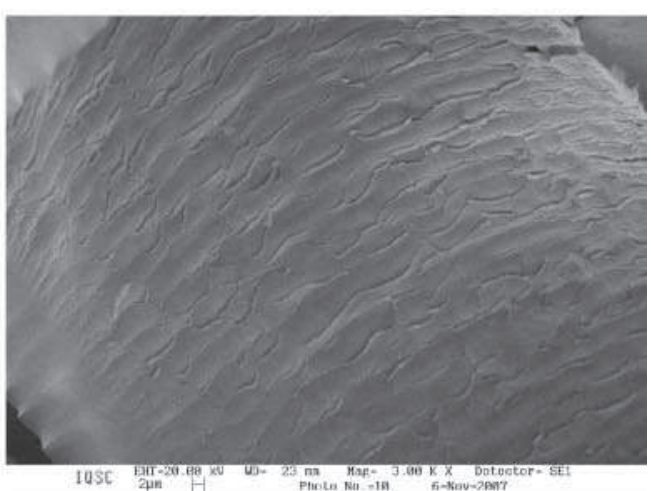

d)

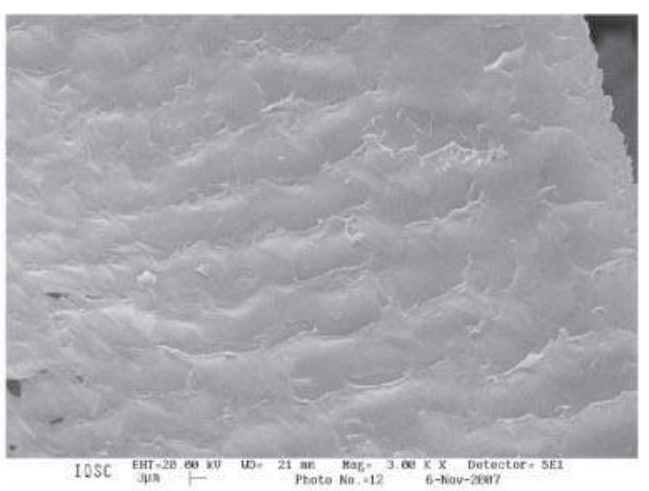

f)

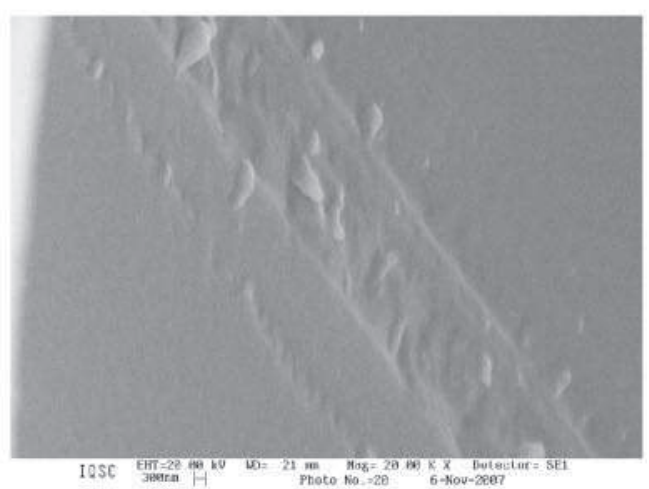

h)

Fig. 6 Scanning electron microscopy images of the chips removed from the surface with different concentrations of CNT and the free surface of the chips showing the lamellar structure: (a) and (b) 0.02 wt \% CNTs; (c) and (d) 0.07 wt \% CNTs; (e) and (f) 0.3 wt \% CNTs; (g) and (h) 0.4 wt \% CNTs 
the cross-sectional profile of the sample machined under a feed rate of $15 \mu \mathrm{m} / \mathrm{rev}$ (rough cutting condition) with $0.4 \mathrm{wt} \%$ CNTs. It can be seen that, even though a fine cutting condition is applied with a lower CNT concentration, the brittle mode is still present within the cutting grooves.

The results from the finishing cutting condition were also evaluated. Figures 4 and 5 present threedimensional images and cross-sectional profiles of the samples respectively. In spite of the cutting conditions being fine, the machined surface still presents microcracks (Figs 4(a) to (c)). The machined surface with a higher concentration of CNTs $(0.4 \mathrm{wt} \%)$ preserves the same trend as that shown in the roughing condition (Fig. 4(d)). The cross-sectional profile of the machined surface is also influenced by the formation of microcracks. The peak-to-valley value is also justified by the cross-section of the surfaces. The values are based on the waviness of the profile measured.

The cutting mode is clearly influenced by the concentration of CNTs in the epoxy matrix, even with low concentrations of CNTs. As the percentage of CNTs increases (above $0.3 \mathrm{wt} \%$ ), ductile-mode machining takes place. CNTs are good thermal conductors, helping to eliminate heat from the cutting area, especially at higher concentrations (above the threshold).

\subsection{Analyses of chips removed}

Figure 6 presents SEM images of the lamellae formed along the chips (typically formed on the free surface of the chip, i.e. opposite the tool rake face). All chips shown were removed under the same cutting conditions $(f=15 \mu \mathrm{m} / \mathrm{rev}$, depth of cut $=20 \mu \mathrm{m})$. It is interesting to observe that the chips removed from the samples with 0.07 and $0.3 \mathrm{wt} \%$ CNTs presented small holes in the surface. Although the surface has pits, all the chips presented a ribbonlike form, which is typical of the ductile-mode material removal mechanism (commonly observed in ductile metal), but the material behaves in a rather brittle manner - it chips. This lamellar structure is a sign of shear deformation during chip formation. However, the microstructure of the chips removed from the sample with the largest concentration of CNTs (0.4 wt \%) did not present any signs of lamellar structure formation, as seen in Fig. 6 (h) at $20000 \times$ magnification. This can also be seen in Fig. 2, which shows the surface finish along the cutting groove.

\section{CONCLUSIONS}

Results of diamond turning tests on carbon nanotube composites are presented. Samples with smaller quantities of CNTs (0.02 and $0.07 \mathrm{wt} \%)$ showed microcracks within the cutting grooves (perpendicular to the cutting direction). This indicates that the amount of CNTs in the epoxy matrix has a direct influence on the mechanical properties of these materials. The area average surface roughness $\left(S_{\mathrm{a}}\right)$ in most tests is below $1 \mu \mathrm{m}$. The $S_{\mathrm{a}}$ values (also influenced by the material removal mechanism) are $0.1980 \mu \mathrm{m}$ up to $0.9595 \mu \mathrm{m}$ for samples with the lower concentration of CNTs and the largest concentration respectively. When the percolation threshold is largely overcome, the surface morphology is changed. This observation is important in order to minimize the quantity of CNTs added to modify the properties. It can be anticipated that other materials such as silica (already adopted in tyres) could be used to modify the dynamics of the turning process.

\section{REFERENCES}

1 Bachtold, A., Hadley, P., Nakanishi, T., and Dekker, C. Logic circuits with carbon nanotube transistors. Science, 2001, 294, 1317.

2 Hashimoto, A., Suenaga, K., Gloter, A., Urita, K., and Ijima, S. Direct evidence for atomic defects in graphene layers. Nature, 2004, 430, 870.

3 Ebbesen, T. W., Lezec, H. J., Hiura, H., Bennett, J. W., Ghaemi, H. F., and Thio, T. Electrical conductivity of individual carbon nanotubes. Nature, 1996, 382, 54.

4 Hone, J., Whitney, M., Piskoti, C., and Zettl, A. Phys. Rev. B, 1999, 59, R2154.

5 Berber, S., Kwon, Y. K., and Tomanek, D. Unusually high thermal conductivity of carbon nanotubes. Phys. Rev. Lett., 2000, 84, 4613.

6 Barrau, S., Demont, Ph., Peigney, A., Laurent, Ch., and Lacabane, C. Effect of palmitic acid on the electrical conductivity of carbon nanotubes-epoxy resin composites. Macromolecules, 2003, 36, 5187.

7 Hussain, F., Hojjati, M., Okamoto, M., and Gorga, R. E. Polymer-matrix nanocomposites, processing, manufacturing, and application: an overview. J. Composite Mater., 2006, 40(17), 1511-1575.

8 Bassil, A., Puech, P., Bacsa, W., Pizani, P. S., Jasinevicius, R. G., Demont, Ph., Barrau, S., Lacabanne, C., Bacsa, R., and Flahaut, E. Laser induced modifications of carbon nanotube composite surfaces. Jap. J. Appl. Phys., 2006, 45(10A), 7776-7779.

9 Carr, J. W. and Feger, C. Ultraprecision machining of polymers. Precision Engng, 1993, 15, 221-237.

10 Gubbels, G. P. H. Diamond turning of glassy polymers. PhD Thesis, Technische Universiteit Eindhoven, Eindhoven, The Netherlands, 2006, 199 pp. 